\title{
Legal Central Bank INDEPENDENCE AND INFLATION IN LATIN AMERICA DURING THE 1990s
}

\author{
Luis I. Jácome $\mathrm{H}^{1}{ }^{\text {* }}$
}

\footnotetext{
${ }^{1}$ I would like to thank, without implication, to Mariano Cortez, Simón Cueva, Steven Dunaway, Eva Gutiérrez, Alain Ize, Roberto Junguito, Alfredo M. Leone, Pamela Madrid, Arne Petersen, DeLisle Worrel, and to the seminar participants at the Central Bank of Bolivia and the IMF's Monetary and Exchange Affairs Department, for useful comments and suggestions on earlier versions of this paper.

* This version is a summary of the original IMF Working Paper WP/01/212 authorized for publication in the present issue of the Revista de Análisis by Mr. Jácome.
} 


\section{ABSTRACT}

The views expressed in this Working Paper are those of the author(s) and do not necessarily represent those of the IMF or IMF policy. Working Papers describe research in progress by the author(s) and are published to elicit comments and to further debate.

This paper reviews central banks' legal reform in Latin America during the 1990s and discusses the status of central bank independence in the region. Based on this information, it builds a simplified index of central bank independence which, in addition to the commonly used criteria of political and economic independence, incorporates provisions of central banks' financial autonomy, accountability, and lender-of-last-resort. The paper finds a moderate negative correlation between increased central bank independence and inflation during 1999-2001 in 14 Latin American countries. Dissagregating the index, the same analysis suggests that economic independence is the key component driving the observed negative correlation between legal central bank independence and inflation.

JEL Classification Numbers: B5, B59

Keywords: Central bank independence, inflation, Latin American countries 


\section{INTRODUCTION}

The decade of the 1990s brought profound changes to central bank legislation in many countries of the world, including those of Latin America. The common denominator in these changes was the autonomy grantedat different degrees - to central banks in the design and execution of monetary policy as a means of securing price stability. The legal reforms were aimed at ending the prolonged period of high inflation rates during which governments had tended to use monetary policy for short-term political purposes, that is, to finance their fiscal deficits or to stimulate economic activity and reduce unemployment.

Today, inflation has declined to single-digit levels in all but a few Latin American countries but must be further reduced to bring it to international levels. However, the environment in which this renewed anti-inflationary effort must be undertaken has become more complex, mainly because most countries of the region have become more closely integrated into international capital markets, which have made them increasingly vulnerable to the volatility of those markets. As a result, Latin American emerging countries find themselves plunged into recurring episodes of financial instability, and central banks are required to increase interest rates to higher levels than those that were previously consistent with the same policy stance, that is to avoid exchange rates pressures and inflation. In addition, since Latin America appears to have entered into a cycle of slower economic growth, the markets are becoming increasingly intolerant to persistent high real interest rates that may hold back economic growth. In this environment, governments may be tempted to use monetary policy in one way or another to gain some additional flexibility in economic policy to stimulate growth.

Given that ultimately inflation is a monetary problem, it is reasonable to assume that the new autonomy granted to central banks contributed to the decline of inflation in Latin America during the 1990s, although this has not been empirically demonstrated. What is less clear is how the different degrees of autonomy or independence conferred to central banks are 
related to this outcome. ${ }^{2}$ In this perspective, the purpose of this paper is twofold. It first seeks to characterize the current status of central bank independence in Latin American countries, which allows us to build a simplified index of central bank independence and accountability applicable to each country. And second, based on these indexes, the paper is intended to extract some empirical regularities about an eventual correlation between increasing legal central bank independence and accountability and inflation in Latin America during the 1999-2001 period.

Obtaining some empirical evidence on whether there is any correlation between increased central bank independence and inflation in Latin America is relevant. First, from an academic perspective, this paper is a preliminary test of the empirical foundations underpinning central banks' institutional reform in Latin America, an issue that has not been examined in relation to the Latin American countries, as oppose to what is available for other regions. ${ }^{3}$ Second, from an economic policy point of view, this subject is important because central bank reform is still in the process of consolidation in most countries of the region, which implies that the central bank reform can still be-at least partially-reversed. Evidence of this trend includes the recent changes to the central bank charter in Argentina by issuing executive decrees; or the transfer to the government of central bank's unrealized revaluation gains on foreign exchange assets and liabilities in Venezuela in 2000 and 2001, among others. And third, finding some empirical evidence on whether there is any correlation between increased central bank independence and inflation in Latin America deserves attention because the reform of the central bank charters has been the subject of the Fund's technical assistance missions to more than 70 member countries, including 14 countries in Latin America.

\footnotetext{
${ }^{2}$ In this paper, the terms "autonomy" and "independence" are used interchangeably, as in other similar papers. However, rigorously speaking, they have different implications since autonomy implies operational freedom, and independence refers to the absence of institutional constraints (Lybek, 1998).

${ }^{3}$ To mention a few examples, see the seminal papers by Grilli, Masciandaro, and Tabellini (1991), and Alesina and Summers (1993) for industrial countries. In addition, Loungani and Sheets (1997) for transition economies, Mehran and others (1998) for the Sub-Saharan African countries, and Lybek (1999) for the former Soviet Union countries. Not to mention the two studies conducted by Cukierman (1992) and Cukierman, Webb, and Neyapti (1992) for a large sample of industrial and developing countries.
} 
The paper is structured as follows. Section II reviews the nature of the autonomy that Latin American central banks now enjoy, primarily in the context of what the International Monetary Fund (IMF) considers "best practices" in the design of central banks autonomy and accountability. Section III endeavors to build a simplified index of central bank independence and accountability, which is then applied to a group of 14 Latin American countries to measure individually the degree of central banks independence. Section IV develops an empirical analysis in order to assess the level of correlation between different degrees of legal central bank independence and accountability and the performance of inflation during the period 1999-2001. Section V summarizes the main conclusions.

\section{Central Bank Independence And Account-Ability In LATIN AMERICA}

The early 1990s saw major structural reforms in Latin America, which were aimed at consolidating stabilization efforts and to pave the way for achieving sustained economic growth. ${ }^{4} \mathrm{~A}$ key component of these reforms was the strengthening of central banks autonomy aimed at allowing monetary policy to focus on reducing inflation and preserving price stability. Several countries in Latin America reformed central bank legislation during the late 1980s and the 1990s-Chile (1989), El Salvador (1991), Argentina (1992), Bolivia (1995), and more recently Nicaragua (1999). (See Annex II for more details).

\section{A. Best Practices on Central Bank Independence and Accountability}

The main components of central banks reform relate to the following five broad criteria:

(i) defining the primary objective of the central bank; (ii) instituting political independence for the design and execution of monetary policy; (iii) granting

\footnotetext{
${ }^{4} \mathrm{~A}$ number of studies have assessed the costs of inflation in terms of economic growth. Empirical evidence suggests a negative correlation between inflation and growth, which becomes stronger at higher levels of inflation. See for example Fischer (1993) and Sarel (1996), and De Gregorio (1992) in relation to Latin American countries.
} 
economic independence; (iv) establishing financial autonomy; and (v) defining accountability procedures. A thorough review of what might be considered best practices in such reforms can be found in Lybek (1998). Box 1 provides a summary of these recommendations classified in terms of the five criteria identified above, which are briefly discussed in the following paragraphs.

(i) The single or primary objective of the central bank should be to preserve price stability. When multiple objectives are defined, price stability should prevail in cases where policy conflicts may arise. Having a single and clearly defined objective will facilitate the definition and monitoring of policy goals and will facilitate accountability, thereby reinforcing transparency, credibility and, in the end, the effectiveness of monetary policy.

(ii) Political independence is closely related to the independence of the central bank's Board of Directors vis-à-vis the government and the private sector so that the central bank is entitled with an undisputed authority to fulfill its legal mandate and to design monetary policy. As a result, conflicts of interest are avoided. In addition, the definition of clear mechanisms to resolve eventual policy conflicts between the central bank and the government strengthen political autonomy. Directors should be appointed in a two-step process, that is, the government should nominate/appoint them and the Legislature should appoint/confirm them, preferably for a longer period than the presidential term, in order to separate their terms of service from that of the nominating or appointing authorities. For the same reason, it is important that a director's removal should only be for violations that are strictly codified in legislation under request of the Executive branch. However, dismissal should be examined and sanctioned either by a high level Judicial Court or by the Legislature with a qualified majority.

(iii) Economic autonomy refers to central bank freedom to formulate and implement monetary policy. The central bank should have autonomy to use monetary instruments. The central bank should 
have autonomy to use monetary instruments in pursuit of its policy target (instrument independence) for the medium-term. Interest rates policy should be an exclusive responsibility of the central bank, while exchange rate policy could be shared with the government with a conflict resolution procedure in favor of the central bank in case a policy conflict arises, limiting implementation of monetary policy. It is less desirable to give the central bank autonomy in setting objectives (goal independence), such as, for instance, to set unilaterally an inflation target. This should be negotiated with the government. Economic autonomy should also include a legal prohibition or severe limitations on government financing-consistent with central bank's financial programming and the policy target-from the central bank, since this is often the key root of inflation. Such a constraint eliminates a major source of fiscal deficit financing, and hence, may encourage a more orderly management of public finances.

(iv) Financial autonomy implies that the government must ensure the central bank's capital integrity in order to support policy autonomy. In return, central banks must transfer profits to governments, after making the appropriate legal reserve provisions. ${ }^{5}$ Operationally, financial autonomy allows the central bank to conduct open market operations (OMOs) without financial restrictions. In addition, central banks should not handle quasi-fiscal operations which, in general, deteriorates their financial position. Central bank financial independence and the transparency of its financial relations with the government will also facilitate accountability.

\footnotetext{
${ }^{5}$ Unrealized revaluation gains stemming mainly from the revaluation of foreign exchange assets and liabilities should not be transferred to the government, in order to avoid a source of inappropriate monetization. In turn, they should be allocated to a separate account aimed at providing an additional buffer to confront eventual losses that could impair central bank's capital.
} 
Box 1. Summary of Best Practices on Central Bank Independence AND ACCOUNTABILITY

\begin{tabular}{|c|c|}
\hline Criteria & Best Practices \\
\hline Clarity of objectives & $\begin{array}{l}\text { Establish a single or primary objective in terms of preserving price } \\
\text { stability. If there are multiple objectives (for example, price stability } \\
\text { and financial system stability), any policy conflict that arises should } \\
\text { be resolved in favor of price stability. }\end{array}$ \\
\hline Political autonomy & $\begin{array}{l}\text { Central bank's Board of Directors must be nominated and } \\
\text { appointed by the government and Congress in a two-step process, } \\
\text { without any representation of the government or the private sector. } \\
\text { They should be appointed for a term longer than that of the } \\
\text { presidential term, and grounds for dismissal should be solely of a } \\
\text { legal nature and clearly established in law. Although the central } \\
\text { bank Board of Directors itself or the government should take } \\
\text { initiative for the dismissal of a board member, the Legislature or the } \\
\text { Judicial Branch should bear the final decision. }\end{array}$ \\
\hline Economic autonomy & $\begin{array}{l}\text { Provide central banks with instrument independence, that is, the } \\
\text { freedom to use all the means to achieve the inflation target. } \\
\text { Interest rate policy should be the exclusive responsibility of the } \\
\text { central bank, while the selection of the exchange rate regime may } \\
\text { be shared with the government, such that it does not interfere with } \\
\text { the conduct of monetary policy and the achievement of the policy } \\
\text { target. Goal independence, for example defining unilaterally an } \\
\text { inflation target, implies a stronger independence but assigns the } \\
\text { central bank the responsibility of driving the short-run trade-off } \\
\text { between inflation and unemployment, which is more in the nature } \\
\text { of the political authorities decision. Direct credit to the government } \\
\text { should be prohibited or carefully limited in line with the policy } \\
\text { objective. }\end{array}$ \\
\hline Financial autonomy & $\begin{array}{l}\text { Define clear rules governing the relationship between the central } \\
\text { bank and the government in the treatment of central bank losses } \\
\text { and profits. Governments should commit to maintain central bank's } \\
\text { capital, such that monetary policy is implemented without financial } \\
\text { restrictions and focused on established policy objectives, while } \\
\text { central bank profits should be transferred to the government after } \\
\text { an appropriate accumulation of central bank's legal reserves. }\end{array}$ \\
\hline
\end{tabular}




\begin{tabular}{|l|l|}
\hline Accountability & $\begin{array}{l}\text { The central bank should report to the government and the } \\
\text { Legislature on the conduct of monetary policy, and in particular on } \\
\text { the achievement of the long-run inflation policy and the } \\
\text { implementation of actions and policies to that end. Such reports } \\
\text { should be given broad public dissemination. Financial statements } \\
\text { should be published at least once a year under generally accepted } \\
\text { accounting principles, and should be certified by an independent } \\
\text { auditor. Summary balance sheets should be published more } \\
\text { frequently under similar accounting standards, supplemented with } \\
\text { relevant explanatory notes. }\end{array}$ \\
\hline
\end{tabular}

(v) In a democratic society accountability is the other side of the coin when autonomy is granted to the central bank. This generally requires that central banks submit a report to the Executive and Legislative branches and, in general, that the bank publicly discloses this information. The report should focus on the achievement of the policy target announced for the period in question, including actions and decisions taken by the central bank to meet that target. In addition, central banks may publish the minutes of the Board of Directors meetings after a given period. On the other hand, central banks are required to publish independently audited financial statements under international accounting standards at least once a year, and to provide more frequent summaries of their financial data under similar accounting standards, accompanied by explanatory notes on the most important items, including administrative and salaries' expenses.

\section{B. Legal Central Bank Independence and Accountability in Latin America}

Central bank independence and accountability was widespread established in Latin America during the 1990s with a few exceptions. On the basis of information drawn from central bank legislation and from national constitutions, the main characteristics of the legal framework supporting monetary and exchange rate policies in Latin American countries are discussed below. Annex I provides a summary of the current status of 15 countries, including Brazil, Dominican Republic, and Guatemala, although these countries have not yet adopted a modern 
institutional reform. ${ }^{6}$ Ecuador and El Salvador were excluded because although they also reformed their central bank laws in the early 1990s, they recently adopted the U.S. dollar as legal tender, and hence, existing central bank legislation is of less interest for the purpose of this paper.

The reforms undertaken to date have embraced price stability as the single or the primary objective of the central bank in a number of countries. However, in some other countries central banks have still been assigned multiple objectives-including the stability of the financial system in Paraguay and Uruguay-which at times may place the central bank in policy conflicts in the absence of any established rank of objectives or conflict resolution procedures.

Central banks in Latin America have gained legal political independence through reforms that, in most cases, call for the Board of Directors to be independent of the government and the private sector. ${ }^{7}$ The term of office for directors, when exceeds or overlaps the constitutional government period, has also contributed toward this goal. In order to reduce linkages between central bank governance bodies and the Executive branch, the Legislative branch is involved in the appointment of central bank directors in most cases. In addition, only half of the countries have eliminated the tradition of giving the President of the Republic the power to remove central bank directors, and have adopted a procedure whereby it is the Legislative or the Judicial branch that approves dismissal on grounds strictly codified in law. Another source of political autonomy weakness is observed in countries, such as Venezuela and Honduras, where central bank directors may be simultaneously private bank shareholders without limit on banks' capital; in Peru this limit is set at 5 percent of the private

\footnotetext{
${ }^{6}$ However, Brazil has recently issued lower rank regulations, without amending the central bank law, in a move to strengthen institutional credibility, accountability, and transparency in the management of monetary policy, as part of the implementation of an inflation targeting scheme.

${ }^{7}$ The Dominican Republic and Guatemala, and to some extent Brazil, are exceptions to this regional trend. The first two countries still have a central bank board (known as the "Monetary Board") in which the government is heavily represented, and in Guatemala the private sector, including a delegate of the private banks, is also represented. In Brazil, the central bank Board of Directors follows the guidelines of the National Monetary Counsel, which is headed by the Minister of Finance and also includes the President of the Central Bank and the Minister of Planning. In all three cases the structure of the central bank board may at some point give rise to potential conflicts of interest.
} 
bank's capital—still a significant amount in nominal terms.

There has been widespread progress in terms of the economic independence of central banks, in particular, regarding the prohibition or the adoption of severe limitations on central bank financing of the fiscal deficit. Also, central bank freedom to conduct interest rate policy is a

Note of Editor: (This blank space is displayed exactly like the print edition). Nota del Editor: (Este espacio en blanco se muestra exactamente igual a la edición impresa). 
general practice. ${ }^{8}$ Notwithstanding, directly financing budget liquidity shortfalls is permitted-although in limited amounts and over a short-run period-in a number of countries such as Bolivia, Costa Rica, Honduras, Mexico, Nicaragua, Paraguay, and Uruguay. On the other hand, in Venezuela the government shares with the central bank responsibilities for the conduct of exchange rate policy, while in Mexico, the central bank has only an indirect responsibility in exchange rate policy through the Exchange Commission, where any decision requires the support of at least one member acting in representation of the Ministry of Finance. Government participation in the conduct of exchange rate policy may restrict central bank's operational independence given the tight link between monetary and exchange rate policies, in particular in economies with high capital mobility.

The economic autonomy granted to central banks may be diminished in cases where the role of the central bank as lender-of-last-resort (LOLR) to the financial system is highly discretionary and even permissive. This is particularly dangerous when price stability is not defined as the primary objective of the central bank, and specifically when the central bank has been legally assigned the responsibility of preserving the stability of the financial system. If there is no limit on the assistance that central banks can provide to troubled financial institutions, as in most Latin American countries, this could ultimately derail monetary policy and divert it from the objective of preserving price stability. In addition, monetary discipline is more vulnerable when central banks become involved in handling financial crises and facilitating monetary resources for bank restructuring.

Despite the progress achieved in reforming central bank legislation, the record of financial autonomy of central banks is still poor. While capital integrity is legally assured in Colombia, Peru, and Venezuela, in the rest of the countries the government is not obliged to maintain the value of central bank's capital. Moreover, there are situations where the central bank accumulates losses stemming from monetary operations (Costa Rica, Guatemala), which typically are not appropriately reflected in the central bank's financial statements, as an artificially device aimed at preventing

${ }^{8}$ Although the Brazilian Constitution sets a limit to the maximum interest rate, this rule has never been placed in operation, since it has not formally been regulated. 
that an appropriate accounting wipe out central bank's capital. On the other hand, there are also countries where the central bank's budget is approved by Parliament (Bolivia, Honduras) or directly by the Executive branch (Argentina), which in the end may be just another way of limiting the central bank's financial autonomy, and to some extent its political autonomy.

Accountability of central banks in Latin America have improved after the institutional reform, but transparency of policy formulation, and in relation to the disclosure of financial statements of central banks is still weak. Several countries, including Argentina, Bolivia, Brazil, Chile, Colombia, Honduras, Mexico, Uruguay, and Venezuela, have rigorous accountability requirements. The governor of the central bank must inform the Executive branch and Congress-or a specialized committee-of the results of the central bank's monetary policy and other activities, and of the extent to which policy goals have been achieved. At the other end, in a few cases (for example Nicaragua), legislation merely requires the publication of an annual report, which ends up being only of academic interest given the delay with which such reports are generally disclosed and published. On the other hand, central bank reform in several countries makes no provision for the transparency of financial statements, and hence, central bank transactions are not always properly recorded. As a result, balance sheets do not always reveal the insolvency resulting from operational losses-which may have been accumulated over the years-because of improper accounting procedures. Or they may fail to make appropriate provisions on the basis of generally accepted accounting principles for poor quality assets, for example, those acquired in the context of a banking crisis.

In short, today central banks in Latin America have greater autonomy in the design and conduct of monetary policy, which is focused on preserving price stability. The most notable features of the reforms that have been undertaken are the general restriction to the monetization of fiscal deficits (except in cases of national emergency or disasters), and the instrument independence granted to central banks, including the autonomy to conduct interest rates policy. On the other hand, the two aspects of greatest 
vulnerability appear to be the lack of financial independence of central banks with respect to the government, and the excessive discretion in the role of central banks as LOLR to the financial system. Other weaknesses observed in a number of countries is the limited transparency and disclosure of financial statements and, most important, the leeway that governments still enjoy in several countries in the region to remove central bank governors and members of the central bank's Board of Directors.

\section{An Index Of Legal Central Bank Independence and ACCOUNTABILITY AND ITS APPLICATION IN LATIN AMERICAN COUNTRIES}

This section is devoted to constructing an index of legal central bank independence and accountability (ICBI), which will then be applied to the Latin American countries. This exercise is as an attempt to quantify the degree of independence of central banks in the formulation and implementation of monetary policy after the adoption of the institutional reform during the first part of the 1990s. The proposed index reflects exclusively legal provisions, which may not be consistent with actual practices. In fact, this is the main caveat of the methodology followed in this paper and in others of the same kind. The main discrepancies between de jure and effective independence of central banks emerge in relation to their political independence, accountability, and in policy and operational transparency.

A number of studies have built these indexes with the aim of determining whether there is any association between central bank independence and lower inflation rates. Most analyses have focused on industrial countries, although more recently interest has shifted to the developing economies. The general thrust of the results of these studies is that, when the sample includes only industrialized countries, there is an inverse relationship between central bank autonomy and inflation, but not when it comes to developing countries. ${ }^{9}$ With respect to Latin America, no recent studies are

\footnotetext{
${ }^{9}$ See for example, Grilli, Masciandaro and Tabellini (1991), Cukierman, Webb, and Neypati (1992), Alesina and Summers (1993), Eijffinger and Schaling (1993), and Eijffinger, Schaling, and Hoeberichts (1998). More recently, Mehran and others (1998) did not find a robust relationship between central bank autonomy and inflation for Sub-Saharan African countries. However, Loungani and Sheets
} 
known, although the sample used in the Cukierman studies includes some countries from the region, but the period of time covered precedes that of the reform of central bank legislation referred to in this document.

\section{A. Simplified Index of Legal Central Bank Independence and Accountability}

The traditional indexes [for example, Grilli, Masciandaro, and Tabellini (GMT) and Cukierman] are based on criteria of political and economic independence. In the GMT index, political independence is usually measured in terms of the procedure for appointing central bank governance bodies, the role of government representatives on those bodies, and the objective assigned to the central bank. In all three cases, the lower the degree of government involvement, the higher the political independence enjoyed by the central bank. Economic independence is in turn measured according to the level of central bank financing of the fiscal deficit, and the responsibility for banking supervision assigned to the central bank. ${ }^{10}$ The smaller the central bank involvement in financing the fiscal deficit and in banking supervision, the greater is-in principle-its independence. The Cukierman ICBI is also based on political and economic independence, although it allows for a larger number of categories for each of the two criteria. More recently, IMF-modified ICBIs (Mehran and others, 1998, and Lybek, 1999) also incorporated criteria of accountability and financial autonomy of central banks. ${ }^{11}$

The ICBI built in this section is also based on criteria that measure political and economic autonomy - with some variations - in the formulation and implementation of monetary policy. But in addition, it expands traditional indexes (GMT and Cukierman indexes) incorporating criteria of financial autonomy, and accountability and transparency, like in the IMFXtype indexes, and the design of LOLR mechanisms, which is typically not

(1997) find an inverse relationship between central bank independence and inflation in the transition economies, and so does Lybek (1999) for the countries of the former Soviet Union.

${ }^{10} \mathrm{On}$ the latter, the link arises from the potential influence that the central bank can have on the purchase of public debt instruments by financial institutions, in cases where banking supervision is part of its responsibilities.

${ }^{11}$ Financial autonomy was already taken into account in the seminal study by Bade and Parking (1988). 
included in previous indexes. In particular, the ICBI includes the following additional features:

(i) In terms of political autonomy, in addition to government involvement, private sector participation on the central bank's Board of Directors is penalized in recognition of the fact that the involvement of such members in monetary, financial, and exchange rate decisions can produce conflicts of interest, which may lead to an outcome that differs from the central bank's fundamental long-term objective. A source of conflict of interests may arise in relation to decisions that imply LOLR policies, in particular, when legal provisions assign the central bank a high degree of discretion for policy formulation and execution;

(ii) The role of the central bank al LOLR is incorporated as a component of the central bank economic autonomy and is an element of the ICBI that is not commonly found in other studies. The relevance of incorporating this criterion is given, first, because central banks are assigned the role of LOLR and on occasions they also have the legal responsibility for overseeing the stability of the financial system, ${ }^{12}$ Second, given the high frequency of banking crises that have occurred in Latin America during the last years in which central banks were involved through different mechanisms that implied unexpected monetization. Box 2 presents a few examples of practical experiences where central banks were involved in banking crises in Latin America, which allows one to appreciate the nature and some policy implications of such involvement. And third, and more important, because central bank support to troubled institutions, when it is abundant and for a prolonged period of time, is equivalent to indirectly financing the fiscal deficit, given that bailing-out a banking crisis is more in the nature of the government role rather than a central bank

\footnotetext{
${ }^{12}$ See Sinclair (2000) for details on this central bank responsibility in 37 countries.
} 
responsibility. ${ }^{13}$

${ }^{13}$ In fact, there are opinions that assert that the function of LOLR is a responsibility that should be handled by governments rather than by central banks, and/or by accessing the international capital market (see for example Dornbusch, 2001). 
Box 2. Central Bank Involvement in Banking Crises Resolution (SELECTED COUNTRY CASES IN LATIN AMERICA)

\begin{tabular}{|c|c|}
\hline $\begin{array}{l}\text { Ecuador } \\
(1998-1999)\end{array}$ & $\begin{array}{l}\text { The banking crisis of } 1998 \text { and } 1999 \text { led to the closure, or the taking over by } \\
\text { the State, of } 16 \text { banks ( } 65 \text { percent of total assets), including four of the five } \\
\text { largest banks. The Central Bank of Ecuador (CBE) was actively involved in } \\
\text { this crisis, initially through LOLR facilities, and subsequently via the payment } \\
\text { of deposit guarantee claims. In return, the CBE received fixed assets and } \\
\text { the lending portfolios of those institutions, as well as government paper. As } \\
\text { a result, the CBE's assets grew by a factor of } 12 \text { between } 1997 \text { and } 1999 \text {. } \\
\text { The size of the crisis made it impossible to sterilize monetization in full, and } \\
\text { control over monetary policy was therefore lost. CBE's financial statements } \\
\text { did not show losses associated with these transactions because the CBE } \\
\text { charged a penalty interest rate on its liquidity loans and because } \\
\text { government paper was discounted at market values. However, provisions } \\
\text { stemming from bad loans were not made in accordance with international } \\
\text { standards, and thus its balance sheet does not reflect its true financial } \\
\text { position. }\end{array}$ \\
\hline $\begin{array}{l}\text { Guatemala } \\
\text { (2001) }\end{array}$ & $\begin{array}{l}\text { The cost of the intervention of three small banks (about } 6 \text { percent of total } \\
\text { deposits) has been absorbed for the time being by the Bank of Guatemala } \\
\text { (Banguat), with no government involvement. Earlier, Banguat provided } \\
\text { liquidity loans against assets of the three problem banks. After intervention } \\
\text { took place, the Monetary Board authorized Banguat to extend a line of credit } \\
\text { to the intervened banks to pay their obligations, primarily to depositors. } \\
\text { These funds were provided without receiving any collateral in exchange. } \\
\text { Since the crisis was of minor dimensions, Banguat sterilized monetization } \\
\text { through OMOs. Banguat will presumably absorb the losses that will be } \\
\text { generated when the three banks are liquidated, as the government has no } \\
\text { legal requirements to compensate central bank losses. However, to date } \\
\text { Banguat has made no provisions to cover such losses. }\end{array}$ \\
\hline $\begin{array}{l}\text { Venezuela } \\
(1994)\end{array}$ & $\begin{array}{l}\text { The systemic banking crisis in Venezuela required an intensive involvement } \\
\text { of the Central Bank of Venezuela (CBV). After the collapse of Banco } \\
\text { Latino-the country's second largest bank-another } 12 \text { banks were } \\
\text { subsequently taken over by the State or closed in } 1994 \text { and } 1995 \text {. The CBV } \\
\text { provided LOLR resources directly to a number of institutions or indirectly via } \\
\text { the deposit insurance fund (FOGADE) initially at market interest rates and } \\
\text { latter at below market conditions. In return, the CBV received assets of the } \\
\text { problem banks and claims on FOGADE, which did not fully cover the } \\
\text { emergency assistance provided. Sterilization inflicted a high cost to the CBV } \\
\text { and in the end was insufficient to completely absorb the excess liquidity. As } \\
\text { of today, government obligations to the CBV has not been settled down. In } \\
\text { the mean time, the government has been covering only marginally CBV's } \\
\text { claims, while at the same time it has extracted from the CBV significant } \\
\text { resources to finance public expenditure stemming from CBV's unrealized } \\
\text { accounting profits. }\end{array}$ \\
\hline
\end{tabular}


Thus in the ICBI used in the paper, excessively discretionary mechanisms for providing liquidity to the banking sector are penalized since this assistance may end up jeopardizing price stability objectives, supporting bank insolvency, and potentially financing a bail-out of the banking sector. ${ }^{14}$ On the contrary, ruled and limited LOLR facilities are rewarded because these arrangements tend to favor the strengthening of prudential banking supervision as a mean of preventing banking crises;

(iii) Still in relation to economic independence, the ICBI penalizes government participation in exchange rate policy committees, where government powers go beyond the general scope of selecting and modifying the exchange regime, unless the law envisages a conflict resolution mechanism;

(iv) A criterion that recognizes the degree of financial autonomy of the central bank is also included in the proposed ICBI, assigning optimal value to situations where the government assures the integrity of the central bank's capital, thereby contributing to monetary policy effectiveness. The rationale for government coverage of central bank losses stems from the fact that they are generally associated with insufficient fiscal tightness or the execution of quasi-fiscal operations. In return, central banks should transfer profits to the government once an adequate level of legal reserves is observed, establishing a transparent relationship between the central bank and the government. The lack of these provisions in the central bank law is penalized in the index. Penalty increases if the central

\footnotetext{
${ }^{14}$ There are also arguments in the literature in favor of a certain degree of discretion in the role of LOLR, particularly during banking crises. See for example, the criterion of "constructive ambiguity," Enoch, Stella, and Khamis (1997).
} 
bank is allowed to conduct quasi-fiscal operations, which contribute to eventual central bank losses; and,

(v) The ICBI incorporates requirements for central bank accountability, including transparency in recording central bank operations and disclosing financial statements. Central bank independence may not survive in the long run if simultaneously central banks are not held accountable. ${ }^{15}$ In turn, the lack of transparency provisions may weaken central bank's autonomy and credibility. Enhancing transparency of central bank actions and monetary policies is today part of the agenda of the international financial community. Multilateral international institutions have prepared guidelines defining and recommending best practices on monetary transparency. ${ }^{16}$ The submission of a timely report to the Executive and Legislative branches, which is then openly disclosed is rewarded. Similarly, the disclosure of central bank financial statements certified by an independent auditor is also rewarded. Alternatively, the ICBI penalizes the simple publication of annual reports by the central bank, which tend to be merely of academic interest, or the lack of disclosure of central bank's financial statements.

\footnotetext{
${ }^{15}$ As stated by Stiglitz (1998), central banks must be held accountable, considering that their governance bodies concentrate in one or a few individuals the power to take decisions that have a determining impact on short-term macroeconomic policies.

${ }^{16}$ The "Code of Good Practices on Transparency in Monetary and Financial Policy: Declaration of Principles," was approved in September 1999 by the international community through the International Monetary and Financial Committee (the former Interim Committee of the Board of Governors of the IMF).
} 
TABLE 1. INDEX OF Central BANK INDEPENDENCE AND ACCOUNTABILITY

(CRITERIA, VALUES, AND WEIGHTS)

\begin{tabular}{|c|c|c|c|}
\hline Criteria (weight) & 1 & 0.5 & 0 \\
\hline $\begin{array}{l}\text { 1. Central bank } \\
\text { objective ( } 2 \text { ) }\end{array}$ & $\begin{array}{l}\text { Preserving price stability is the } \\
\text { single objective. If more than } \\
\text { one conflicting objective, price } \\
\text { stability has priority. }\end{array}$ & \begin{tabular}{lr} 
Multiple & conflicting \\
objectives & without \\
establishing & that \\
preventing price & stability \\
\multicolumn{2}{l}{ has priority. } \\
\end{tabular} & $\begin{array}{l}\text { Multiple objectives, including } \\
\text { growth, an orderly } \\
\text { development, or economic } \\
\text { development, without priorities. }\end{array}$ \\
\hline $\begin{array}{l}\text { 2. Appointment and } \\
\text { term of office of the } \\
\text { members of the } \\
\text { Central Bank Board } \\
\text { (2) }\end{array}$ & $\begin{array}{l}\text { Nominated (appointed) by } \\
\text { government and appointed } \\
\text { (confirmed) by Congress. } \\
\text { Term in office exceed or } \\
\text { overlap government period. }\end{array}$ & $\begin{array}{l}\text { Nominated and appointed } \\
\text { in a two-step process for } \\
\text { same term in office than } \\
\text { government without over- } \\
\text { lap, or directly for longer } \\
\text { term. }\end{array}$ & $\begin{array}{l}\text { Appointed directly by the } \\
\text { government for the same or } \\
\text { shorter period than the } \\
\text { government. }\end{array}$ \\
\hline $\begin{array}{l}\text { 3. Structure of } \\
\text { Central Bank Board } \\
\text { (3) }\end{array}$ & $\begin{array}{l}\text { No private sector and } \\
\text { government representatives, } \\
\text { except Min. of Finance without } \\
\text { vote. }\end{array}$ & $\begin{array}{l}\text { Direct government } \\
\text { representation, including } \\
\text { Minister of Finance with } \\
\text { vote. }\end{array}$ & $\begin{array}{l}\text { Direct government plus private } \\
\text { sector representatives } \\
\text { (bankers, entrepreneurs, etc.) }\end{array}$ \\
\hline $\begin{array}{l}\text { 4. Removal of } \\
\text { Board members (2) }\end{array}$ & $\begin{array}{l}\text { Two-step process, with } \\
\text { qualified majority under strictly } \\
\text { legal grounds. Final decision } \\
\text { by Congress or Judicial Court. }\end{array}$ & $\begin{array}{l}\text { Directly by the Executive } \\
\text { branch under strictly legal } \\
\text { grounds, or in two-step } \\
\text { process under non-legal } \\
\text { basis. }\end{array}$ & $\begin{array}{l}\text { Removal by the Executive } \\
\text { branch for subjective or } \\
\text { political—not legal—grounds, } \\
\text { or by the private sector. }\end{array}$ \\
\hline $\begin{array}{l}\text { 5. Central Bank } \\
\text { credit to } \\
\text { government (3) }\end{array}$ & $\begin{array}{l}\text { No direct credit, except in } \\
\text { clearly regulated emergency } \\
\text { situations. Or through the } \\
\text { secondary market, with } \\
\text { limitations. }\end{array}$ & $\begin{array}{l}\text { Direct credit with limits, } \\
\text { via secondary market } \\
\text { without limits, through } \\
\text { overdrafts, or indirectly } \\
\text { via public banks. }\end{array}$ & $\begin{array}{l}\text { Direct or indirect credit without } \\
\text { limits. }\end{array}$ \\
\hline $\begin{array}{l}6 \text {. Lender-of-last- } \\
\text { resort (2) }\end{array}$ & $\begin{array}{l}\text { Emergency loans legally } \\
\text { regulated, including limits to } \\
\text { the amount to be granted. }\end{array}$ & $\begin{array}{l}\text { Emergency loans legally } \\
\text { regulated, without limits } \\
\text { to the amount to be } \\
\text { granted. }\end{array}$ & $\begin{array}{l}\text { Discretionary policy for } \\
\text { emergency loans and } \\
\text { provisions for bank resolution. }\end{array}$ \\
\hline $\begin{array}{l}\text { 7. Instruments } \\
\text { independence in the } \\
\text { conduct of } \\
\text { monetary policy (3) }\end{array}$ & $\begin{array}{l}\text { Total independence in the use } \\
\text { of monetary instruments. }\end{array}$ & $\begin{array}{l}\text { Government involvement } \\
\text { in formulation of } \\
\text { monetary and exchange } \\
\text { rate policy. }\end{array}$ & $\begin{array}{l}\text { Limitations on the use of } \\
\text { monetary instruments (reserve } \\
\text { requirements, interest rates). }\end{array}$ \\
\hline $\begin{array}{l}\text { 8.Financial } \\
\text { independence (1) }\end{array}$ & $\begin{array}{l}\text { Government assures central } \\
\text { bank capital integrity. Central } \\
\text { bank transfers profits to the } \\
\text { government after proper } \\
\text { provisioning. }\end{array}$ & $\begin{array}{l}\text { Government not required } \\
\text { to assure integrity of } \\
\text { central bank capital. } \\
\text { External approval of } \\
\text { central bank budget. }\end{array}$ & $\begin{array}{l}\text { Central bank conducts quasi- } \\
\text { fiscal operations. No } \\
\text { government capitalization } \\
\text { required. }\end{array}$ \\
\hline 9. Accountability (1) & $\begin{array}{l}\text { Central bank Governor } \\
\text { appears before Congress and } \\
\text { reports to government. Report } \\
\text { disclosed on a timely basis. }\end{array}$ & $\begin{array}{l}\text { Reports only to the } \\
\text { government on a regular } \\
\text { basis or when there are } \\
\text { monetary disturbances, } \\
\text { plus an annual report. }\end{array}$ & $\begin{array}{l}\text { Central bank only publishes an } \\
\text { annual report. }\end{array}$ \\
\hline $\begin{array}{l}\text { 10. Transparency } \\
\text { and disclosure of } \\
\text { financial statements } \\
\text { (1) }\end{array}$ & $\begin{array}{l}\text { Publishes periodically financial } \\
\text { statements - certified by an } \\
\text { external auditor. }\end{array}$ & $\begin{array}{l}\text { Publishes financial } \\
\text { statements with the } \\
\text { approval of a public } \\
\text { sector auditor. }\end{array}$ & $\begin{array}{l}\text { Inappropriate accounting } \\
\text { procedures. Publishes financial } \\
\text { statements with the seal of } \\
\text { internal auditor. }\end{array}$ \\
\hline
\end{tabular}


Table 1 describes each of the criteria used in the ICBI, including the values and weightings assigned for each criterion. The ICBI incorporates most of the criteria used in the GMT and Cukierman indexes as well as the innovations identified above, which result in a 10-criteria index. Specifically, criterion 1 refers to the objective legally assigned to central banks; criteria 2 to 4 are related to the political autonomy of the central bank; criteria 5 to 7 refer to its economic autonomy; 8 to its financial autonomy; whereas criteria 9 and 10 are linked to the accountability and transparency of central banks' policies and procedures. The values assigned to each of the 10 criteria are $0,0.5$, and 1 , depending on how the legal provisions are related to such criteria conducive to central bank independence and accountability.

A differentiated weight $(1,2$, and 3$)$ for the individual criteria is another particular characteristic of the ICBI used in this paper. This implies that some of the criteria included in the index are assigned more influence than others in terms of their contribution to central bank independence, and hence, to the difficult endeavor of building and maintaining central bank credibility as a way of eliminating or reducing the inflationary bias. Thus, the autonomy to design and conduct monetary policy, and the prohibition to finance the fiscal deficit are assigned the highest weight (3 points) since they are assumed to be the key factors contributing to the independence of monetary policy and to the reduction of inflation. The objective assigned to the central bank, the institutional procedures for the appointment, term of office, and the dismissal of members of the central bank Board of Directors, as well as the design of LOLR provisions are assigned a weight of 2 points. In turn, the criteria related to financial autonomy, accountability, and transparency are assigned a weight of 1 , which does not imply that the latter are not relevant, but simply that their connection with the objective of preserving price stability may not be appropriately perceived by market participants. As a result of these valuations, the maximum possible score for the ICBI is 19. Needless to say, the structure, values and weights of the ICBI used in this paper, as in similar papers, are discretional and thereby subject to debate. 


\section{B. Measuring Legal Independence and Accountability in Latin American Central Banks}

Central bank independence and accountability is measured under the structure of the ICBI described above for a group of 14 Latin American economies. This is quantified based on the analysis of the countries' constitutions-on their relevant issues-and central banks' charters, except for Brazil where relevant Executive Decrees aimed at strengthening central bank independence and accountability were also taken into account. ${ }^{17}$ A summary of central bank legislation in Latin American countries is presented in Annex II, including Nicaragua, though this country was not incorporated to the empirical analysis given that the central bank reform was adopted just recently. The sample includes the Dominican Republic and Guatemala, because although they have not strengthened central bank autonomy in recent years, their inclusion contribute to a more complete assessment of the level of correlation between an augmented autonomy of central banks and inflation performance. Based on this information indexes of central bank independence and accountability are calculated and ranked in Table 2, which are fueled with the information provided in Table 3, where each country is evaluated for the individual criteria included in the ICBI.

Numerically, the results show that the country with the most independent central bank according to legal grounds is Argentina, with an ICBI of 18.5, followed by Peru and Chile with an ICBI of 17 and 16.5, respectively. Among the countries that already have adopted the institutional reform, Paraguay and Venezuela show the lowest degree of central bank autonomy with an ICBI of 10.5 and 10.0 , respectively.

\footnotetext{
17 The alternative would have been to set aside these reforms given that they do not have a constitutional rank or are not included on a central bank organic law. Of course, we should be aware that such reforms may eventually be subject to backward revisions in the future if the institutional reform is not established on more solid legal basis.
} 
Table 2. Ranking of Legal Central Bank Independence and AccountabiLity in LATIN AMERICAN COUNTRIES

\begin{tabular}{l|lc}
\hline Country & Last Central Bank Organic Law or Constitution & ICBI 2/ \\
\hline Argentina & September 1992 & 18.5 \\
Peru & January 1993 & 17.0 \\
Chile & October 1989 & 16.5 \\
Mexico & December 1993 & 16.0 \\
Colombia 1/ & August 1991 & 15.0 \\
Bolivia & October 1995 & 13.5 \\
Honduras & December 1996 & 13.0 \\
Costa Rica & November 1995 & 12.5 \\
Uruguay & March 1995 & 12.5 \\
Brazil & Constitution 1988, Law 4595/1964, and further & 12.0 \\
Paraguay & Executive Decrees & 10.5 \\
Venezuela & June 1995 & 10.0 \\
Dominican & December 1992 & 7.0 \\
Republic & Central Bank Law 1940, Reform of 1962 & 7.0 \\
Guatemala & Constitution 1985, Central Bank Law 1945 \\
\hline
\end{tabular}

1/ Corresponds to the date when the new independent Central Bank Board was appointed. 2/ The higher the index the more independent is the central bank

As already observed though, these figures do not necessarily reflect actual central bank independence, which inevitably distorts the results of the proposed analysis. For example, the Central Bank of Brazil (CBB) enjoys more effective than legal independence as oppose to the Central Bank of Venezuela (CBV), which on many aspects is legally rather than effectively independent. Financial independence established by law has not been followed in practice (see Box 2), while simultaneously the CBV has been required to transfer to the government unrealized profits. 
Table 3. Central Bank Independence and Accountability (COUNTRY EVALUATION)

\begin{tabular}{|c|c|c|c|}
\hline Criteria (weight) & 1 & 0.5 & 0 \\
\hline $\begin{array}{l}\text { 1. Central bank } \\
\text { objective (2) }\end{array}$ & $\begin{array}{l}\text { Argentina, Bolivia, } \\
\text { Brazil, Chile, Colombia, } \\
\text { Costa Rica, Honduras, } \\
\text { Mexico, Peru }\end{array}$ & Paraguay, Uruguay & $\begin{array}{l}\text { Dominican Republic, } \\
\text { Guatemala, } \\
\text { Venezuela }\end{array}$ \\
\hline $\begin{array}{l}\text { 2. Appointment } \\
\text { and term of office } \\
\text { of members of } \\
\text { Central Bank Board } \\
\text { (2) }\end{array}$ & $\begin{array}{l}\text { Argentina, Bolivia, } \\
\text { Brazil, Chile, Colombia, } \\
\text { Costa Rica, Mexico, } \\
\text { Paraguay, Venezuela }\end{array}$ & Peru, Uruguay & $\begin{array}{l}\text { Dominican Republic, } \\
\text { Guatemala, } \\
\text { Honduras }\end{array}$ \\
\hline $\begin{array}{l}\text { 3. Structure of } \\
\text { Central Bank Board } \\
\text { (2) }\end{array}$ & $\begin{array}{l}\text { Argentina, Bolivia, } \\
\text { Chile, Honduras, } \\
\text { Mexico, Paraguay, } \\
\text { Peru, Uruguay }\end{array}$ & $\begin{array}{l}\text { Brazil, Colombia, Costa } \\
\text { Rica, Venezuela }\end{array}$ & $\begin{array}{l}\text { Dominican Republic, } \\
\text { Guatemala }\end{array}$ \\
\hline $\begin{array}{l}\text { 4. Removal of } \\
\text { Board members (2) }\end{array}$ & $\begin{array}{l}\text { Argentina, Chile, } \\
\text { Colombia, Dominican } \\
\text { Republic, Honduras, } \\
\text { Mexico, Peru }\end{array}$ & $\begin{array}{l}\text { Bolivia, Costa Rica, } \\
\text { Paraguay }\end{array}$ & $\begin{array}{l}\text { Brazil, Guatemala, } \\
\text { Uruguay, Venezuela }\end{array}$ \\
\hline $\begin{array}{l}\text { 5. Central Bank } \\
\text { credit to } \\
\text { government (3) }\end{array}$ & $\begin{array}{l}\text { Argentina, Chile, } \\
\text { Guatemala, Mexico, } \\
\text { Peru, Venezuela }\end{array}$ & $\begin{array}{l}\text { Bolivia, Brazil, } \\
\text { Colombia, Costa Rica, } \\
\text { Dominican Republic, } \\
\text { Honduras, Paraguay, } \\
\text { Uruguay }\end{array}$ & \\
\hline $\begin{array}{l}\text { 6. Lender-of-last- } \\
\text { resort (2) }\end{array}$ & $\begin{array}{l}\text { Argentina, Peru, } \\
\text { Uruguay }\end{array}$ & $\begin{array}{l}\text { Costa Rica, Colombia, } \\
\text { Honduras, Mexico }\end{array}$ & $\begin{array}{l}\text { Bolivia, Brazil, Chile, } \\
\text { Dominican Republic, } \\
\text { Guatemala, } \\
\text { Paraguay, Venezuela }\end{array}$ \\
\hline $\begin{array}{l}\text { 7. Instruments } \\
\text { independence in } \\
\text { the conduct of } \\
\text { monetary policy (3) }\end{array}$ & $\begin{array}{l}\text { Argentina, Bolivia, } \\
\text { Brazil, Chile, Colombia, } \\
\text { Costa Rica, Dominican } \\
\text { Republic, Guatemala, } \\
\text { Honduras, Peru, } \\
\text { Uruguay }\end{array}$ & $\begin{array}{l}\text { Mexico, Paraguay, } \\
\text { Venezuela }\end{array}$ & \\
\hline $\begin{array}{l}\text { 8. Financial } \\
\text { independence (1) }\end{array}$ & $\begin{array}{l}\text { Colombia, Peru, } \\
\text { Venezuela }\end{array}$ & $\begin{array}{l}\text { Argentina, Bolivia, } \\
\text { Brazil, Chile, Costa } \\
\text { Rica, Guatemala, } \\
\text { Honduras, Mexico, } \\
\text { Paraguay, Uruguay, }\end{array}$ & Dominican Republic \\
\hline $\begin{array}{l}\text { 9. Accountability } \\
\text { (1) }\end{array}$ & $\begin{array}{l}\text { Argentina, Bolivia, } \\
\text { Brazil, Chile, Colombia, } \\
\text { Honduras, Mexico, } \\
\text { Uruguay, Venezuela } \\
\end{array}$ & $\begin{array}{l}\text { Costa Rica, Dominican } \\
\text { Republic, Guatemala, } \\
\text { Paraguay, Peru }\end{array}$ & \\
\hline $\begin{array}{l}\text { 10. Transparency } \\
\text { and disclosure of } \\
\text { financial } \\
\text { statements (1) }\end{array}$ & $\begin{array}{l}\text { Argentina, Brazil, Chile, } \\
\text { Mexico }\end{array}$ & $\begin{array}{l}\text { Bolivia, Colombia, } \\
\text { Paraguay, Peru, } \\
\text { Uruguay, Venezuela }\end{array}$ & $\begin{array}{l}\text { Costa Rica, } \\
\text { Dominican Republic, } \\
\text { Guatemala, } \\
\text { Honduras } \\
\end{array}$ \\
\hline
\end{tabular}




\section{Legal Central Bank Independence and Accountability AND INFLATION IN LATIN AMERICA}

Inflation declined significantly in Latin America during the 1990s. As the decade began, average inflation exceeded 600 percent, but at the end of the 1990s the average rate of inflation had plunged to less than 10 percent. This trend also holds true for the majority of individual countries in the region. The deceleration of inflation was achieved in spite of the adverse effects imposed by real and financial shocks, and in some cases by a fiscal stance that was not consistent with the objective of preserving price stability.

Although there is no empirical evidence supporting any form of causation from central bank independence to lower inflation during the 1990s in Latin America, it is possible to assume that some correlation may exist, given that inflation is indeed a monetary phenomenon. A different question is whether an inverse correlation exists between increasing central bank independence and inflation in a similar period. This section presents a simplified empirical analysis based on scattered diagrams to find whether or not there is some degree of correlation between increasing levels of central bank independence and accountability and inflation. Determining causation between the two variables is beyond the scope of this paper. The reader should not expect strong correlations, since such a simplified analytical framework like the one used in this paper, is unable to capture the full dynamics of inflation in Latin America. In fact, although monetary policy is certainly the main factor driving inflation, a number of other explanatory variables have been left out of the analysis, which may also have contributed to the decrease in inflation.

As a first experiment, the ICBI established above is compared to average inflation between 1999 and 2001 in the 14 Latin American countries identified in the previous section. Given that all central bank reforms took place until 1996, the analysis assesses the relationship between the two variables after a lag in order to allow for an adjustment period in which central banks built operational expertise in the conduct of monetary policy under the new rules-in most cases based on recently adopted indirect 
instruments of monetary policy-and also developed credibility on their ability to reduce inflation under the new institutional and legal setting.

The trend line in the scatter diagram (Figure 1) shows an inverse correlation $(-0.46)$ between greater central bank autonomy and accountability and average inflation in the period 1999-2001. To test the robustness of this correlation the lowest and highest inflation countries (Argentina and Venezuela, respectively) are excluded from the sample, although this implies a significant loss of information considering that the sample only comprises 14 countries. As illustrated in Figure 2, the slope of the trend line falls markedly-although it is still negative-which implies that the previous outcome is largely driven by the numbers from these two countries.

FIGURE 1

Legal Central Bank Independence and Average Inflation

(14 LATIN AMERICAN COUNTRIES. 1999-2001)

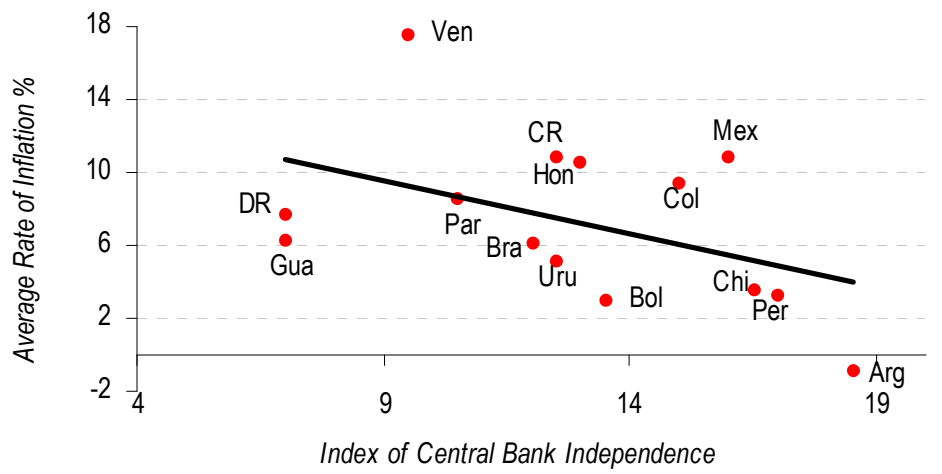


FIGURE 2

Legal Central Bank Independence and Average Inflation

(EXCLUdes Argentina AND VeneZUela. 1999-2001)

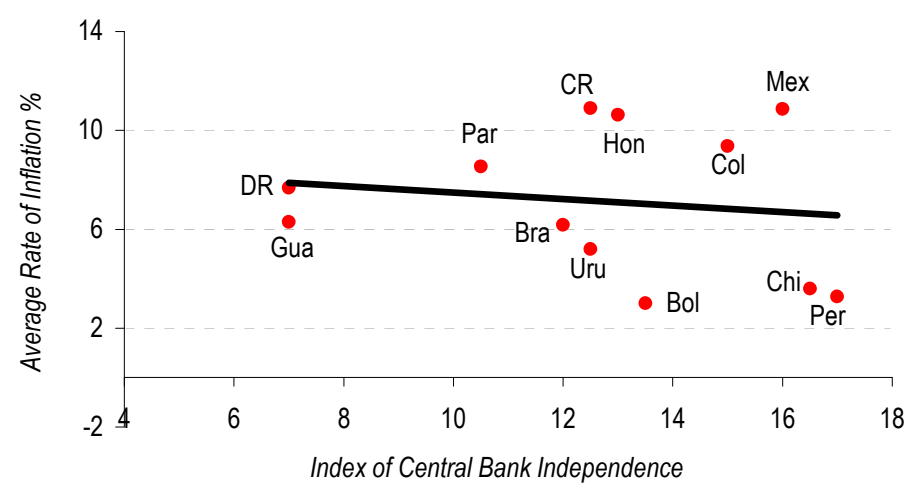

While excluding Argentina from the sample is reasonable, the elimination of Venezuela may be disputed. The rational for the exclusion of Argentina comes from the fact that the fall in inflation stems from the monetary rule and the super-fixed exchange rate embedded on the currency board arrangement rather than from the monetary policy conducted by a conservative central banker. ${ }^{18}$ In the case of Venezuela, though, the high level of inflation observed during the second half of the 1990s is not independent from monetary policy, since it was the result of a systemic banking crisis, which was accompanied by a marked monetary expansion. In fact, monetization was possible given that legislation allowed the CBV to transfer resources to the deposit insurance fund to pay deposits and to provide financial assistance to the troubled banks. In order to illustrate the opposite result, note that Peru and Argentina also experienced banking crises-although less severe than Venezuela-but they did not suffered any inflationary impact, given that they had already built a more appropriate legal and institutional framework to confront banking crisis without the need of undesirable monetization.

\footnotetext{
${ }^{18}$ Although one could also argue that a currency board arrangement will not be sustainable in the long run if the central bank is not independent and expands monetary policy beyond the limits of the convertibility rule.
} 
The second test addresses the issue of whether the reform of central banks may be consistent with a reduced variability and unpredictability of inflation in Latin America. The experiment is relevant since conventional wisdom holds that volatility of inflation tends to discourage investment, and hence, to hamper economic growth. Using the complete sample of countries, Figure 3 shows a mild correlation between central bank independence and accountability and the volatility of inflation. However, while the correlation coefficient is only -0.17 using the entire sample, it increases to -0.55 when Mexico and Venezuela, the two countries with highest standard deviation of inflation are excluded (Figure 4). In the present case, the exclusion of the two countries may be justified since they experienced in fact a sustained decrease in inflation (from 16.6 percent to 7 percent in Mexico and from 24 percent to 12 percent in Venezuela, from 1999 to 2001) rather than an erratic inflation behavior, which nonetheless increases the standard deviation of inflation in the period 1999-2001.

FIGURE 3

Legal Central Bank Independence and Volatility of InfLAtion (14 LATIN AMERICAN COUNTRIES. 1999-2001)

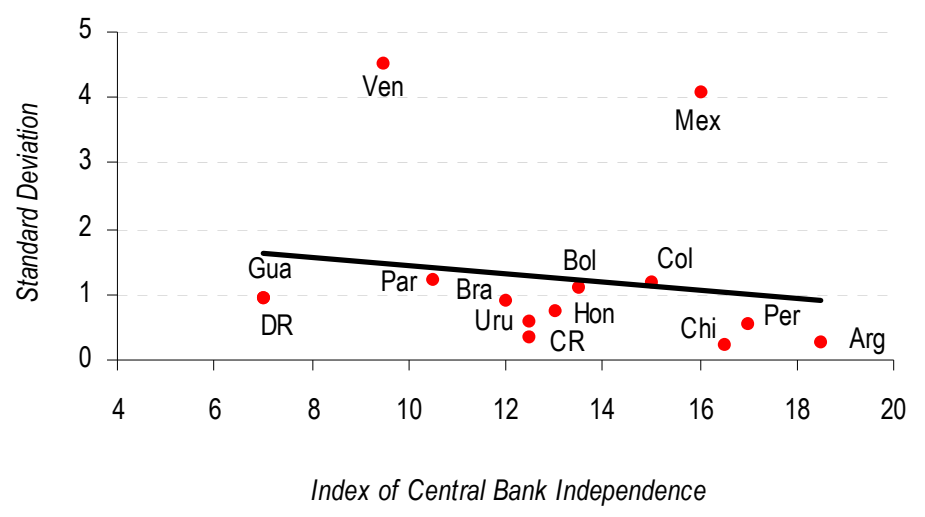


FIGURE 4

Legal Central Bank Independence and VolatiLity of INFLation

(EXCLUdes MeXICO AND VENEZUeLA. 1999-2001)

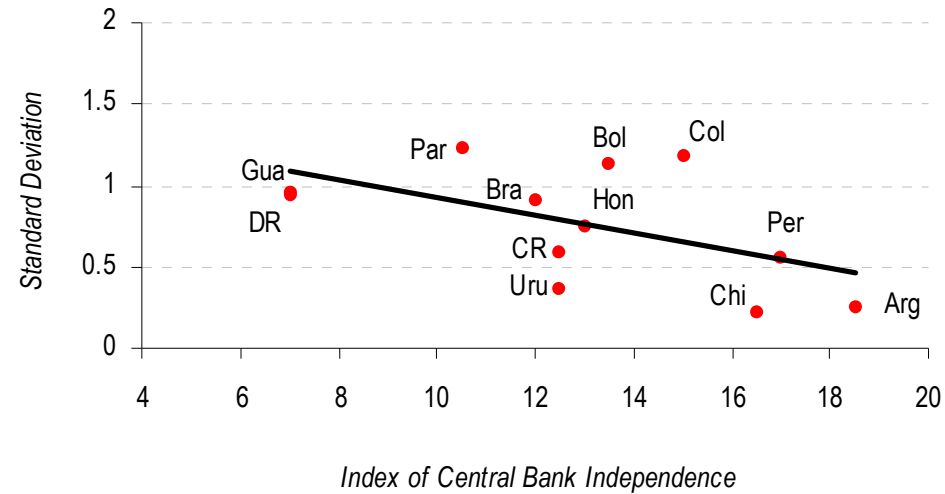

In this connection, a third experiment is conducted relating legal central bank independence and accountability with the decline in inflation in the sample countries. The idea is to ascertain how successful have been more independent central banks in reducing inflation. The rationale of the proposed exercise stems from the fact that most countries in the region used to have very high inflation rates before the adoption of the institutional reform, and that today, although most of them have achieved single-digit inflation rates, inflation is still declining in many countries. A simple index of the decline in inflation is obtained by dividing the number of years in which inflation fell by the total number of years after the adoption of the central bank reform in each country, and hence, a value that is close or equal to one represents a successful anti-inflation policy, and vice versa. In the nonreformed countries, the period considered is 1995-2001, that is the last seven years, which is approximately the average period of time after the reform took place in the other countries of the region.

The trend line in the scatter diagram in Figure 5 shows a positive correlation between greater central bank independence and accountability 
and a decline in inflation, which in principle reveals that central banks with a stronger independence and accountability may have been more successful in reducing inflation following the institutional reform. The relationship between the two variables proves to be robust since the correlation coefficient increased from 0.54 to 0.72 after Argentina and Venezuela were excluded from the sample.

FIGURE 5

Legal Central Bank Independence and Decline of INFLation (14 LATIN AMERICAN COUNTRIES)

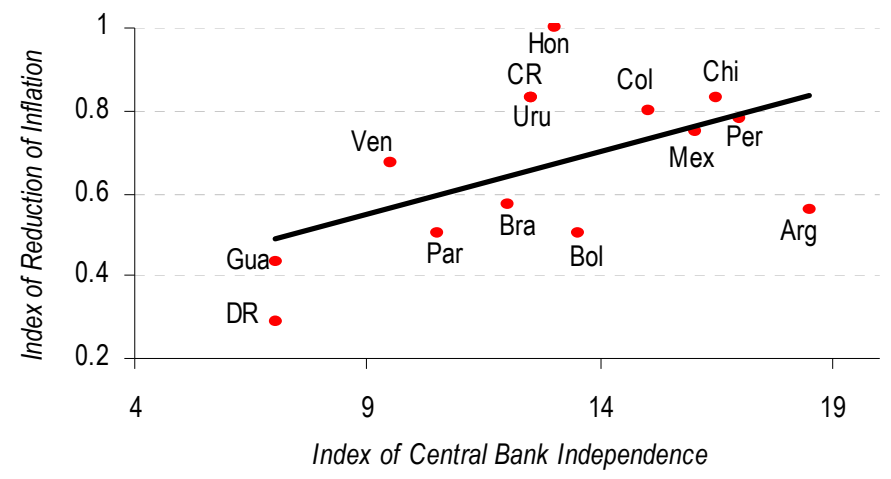

To tackle the problem that de jure central bank independence and accountability does not necessarily mean that such independence is observed in practice, Figure 6 relates inflation with an indicator of effective central bank independence. The index of effective independence of central banks is measured by the degree of turnover among central bank governors, and was initially used in the Cukierman studies. The rationale for using this index as an indicator of effective central bank independence is that a high turnover rate is, in general, a symptom of the government's capacity to remove central bank authorities who are not sympathetic to its short-term policy goals. ${ }^{19}$ The indicator is constructed dividing the number

\footnotetext{
${ }^{19}$ This criterion may also be criticized on the grounds that if a central bank governor remains in office too long, this length of service may be taken as a sign of subordination to government policy dictates. Although on occasions this may be true, in this paper such a situation is considered the exception
} 
of central bank governors by the number of years after the institutional reform was adopted in each country. Therefore, the larger the coefficient obtained, the lower the effective independence of the central bank. The inputs for the calculation of the index in each country are found in Annex II and reveal that in 9 of the 14 countries considered in the analysis, central bank governors lasted on average three years or less, which suggests that in most Latin American countries political independence of central banks is established in words more than in actions.

FIGURE 6

Effective Central Bank Independence and Average InfLAtion

(14 LATIN AMERICAN COUNTRIES. 1999-2001)

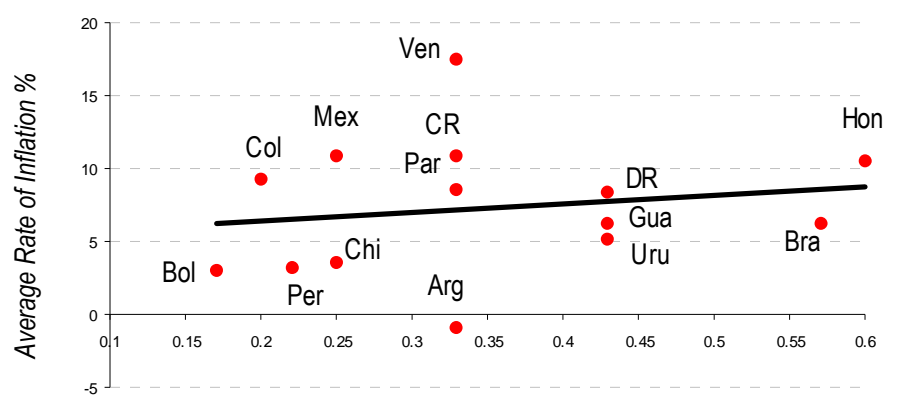

No. of Central Bank Governors per Year

\section{CONCLUDING REMARKS}

Latin America is now experiencing a period of low inflation. With few exceptions, the years of two and three-digit inflation, not to mention hyperinflation, appears to be an issue of the past. Since inflation is essentially a monetary phenomenon, monetary policy should have made a decisive contribution toward this outcome and, consequently, the greater autonomy given to central banks during the 1990s in their conduct of monetary policy may has been beneficial. Yet, inflation in most countries of the region has to converge to world inflation, while central bank autonomy

rather than the rule. 
is still in the process of consolidation under circumstances where new challenges associated with the instability of financial markets have emerged.

From a thorough review of the monetary legislation in force in Latin America, it is noticeable that a consensus has been achieved against monetizing the fiscal deficit, as well as for granting economic autonomy to central banks based on instrument independence. The major flaws in monetary legislation refers to the absence of limits to the central bank mechanisms of LOLR in most countries, which is a potential source of indirect financing to the government during periods of financial distress and crises. In addition, another concern is the lack of financial independence, and the insufficient transparency and disclosure requirements relative to the formulation and execution of monetary policy and to central bank financial statements in a number of countries.

Based on measures of legal independence and accountability in 14 Latin American central banks, the paper found a mild correlation between increasing legal central bank independence and accountability and inflation from 1999 to 2001 . Beyond the usual caveats associated with the analytical framework used in this paper, mainly the gap between legal and effective independence of central banks, the moderate relationship between central bank independence and inflation may be due, to a great extent, to the fact that the nonreformed countries, like Brazil, Guatemala, and the Dominican Republic, with a low ICBI, also managed to reduce inflation down to single-digit rates. This outcome may not be surprising since in all countries in the region, including the last three, central banks are legally prohibited to openly finance the fiscal deficit, while at the same time they have the authority to design and implement monetary policy. Indeed, today central banks in Latin America-reformed and non-reformed countries-at minimum enjoy economic independence, which-if sustained in the long run-is in a way a golden rule to maintaining low inflation. In turn, political autonomy of central banks, although already incorporated in most central bank laws, has not been fully applied, since central banks governors on average lasted slightly less than three years after having adopted the institutional reform of central banks, which is 
clearly below their average term of appointment. This institutional weakness tend to create uncertainty on long-term goals of monetary policy, and hence, may favor the maintenance of an "inflation bias" with respect to the world inflation.

The results obtained in this paper are encouraging for the assessment of the practical results stemming from the reform of central banks in Latin America, and should stimulate further research. The main challenge for future studies should be to reduce the gap between legal and effective central bank independence and accountability in the analytical model to be used. This may be achieved by using an ICBI that is based on legal provisions but also on direct observations and a survey of relevant questions to be answered by central bank officials from the sample countries-something that will certainly shed more light about the importance of central bank independence reform currently in effect in Latin America. 


\section{BIBLIOGRAPHY}

Alesina, A. and L. Summers, 1993, "Central Bank Independence and Macroeconomic Performance: Some Comparative Evidence," Journal of Money Credit and Banking, Vol. 25 (May), pp.1-14.

Bade, R. and M. Parkin, 1988, "Central Banks Laws and Monetary Policy," Working Paper, Department of Economics, University of Western Ontario (October).

Cukierman, A., 1992, Central Bank Strategy, Credibility, and Independence: Theory and Evidence (Cambridge, Mass.: The MIT Press).

and S. Webb, 1995, "Political Influence on the Central Bank: International Evidence," The World Bank Economic Review, Vol. 9, No. 3, pp. 397-423.

, and B. Neyapti, 1992, "Measuring the Independence of Central Banks and its Effect on Policy Outcomes," The World Bank Economic Review, Vol. 6 (September), pp. 352-398.

De Gregorio, J., 1992, "Effects of Inflation on Economic Growth: Lessons from Latin America," European Economic Review, Vol. 36 (April), pp. 417-25.

Dornbusch, R., 2001, "Exchange Rates and the Choice of Monetary Policy Regimes. Fewer Monies, Better Monies," American Economic Review, Papers and Proceedings, Vol. 91, No. 2 (May), pp. 238-242.

Eijffinger, S., and E. Schaling, 1993, "Central Bank Independence in Twelve Industrial Countries," Banca Nazionale de Lavoro Quarterly Review, No. 184 (March), pp. 49-89. 
E. Schaling, and M. Hoeberichts, 1998, "Central Bank Independence: A Sensitivity Analysis," European Journal of Political Economy, Vol. 14, pp. 73-88.

Enoch, C., P. Stella, and M. Khamis, 1997, "Transparency and Ambiguity in Central Bank Safety Net Operations," IMF Working Paper 97/138 (Washington: International Monetary Fund).

Fischer, S., 1993, "The Role of Macroeconomic Factors in Growth," Journal of Monetary Economics, Vol. 32 (December), pp. 484512.

Grilli, V., D. Masciandaro, and G. Tabellini, 1991, "Political and Monetary Institutions and Public Financial Policies in the Industrial Countries," Economic Policy: A European Forum, Vol. 6 (October), pp. 342-91.

Leone, A., L. Jácome, and P. Madrid, 2001, "Bank Restructuring and Central Banks in Latin America," IMF Working Paper, forthcoming, (Washington: International Monetary Fund).

Loungani, P., and N. Sheets, 1997, "Central Bank Independence, Inflation, and Growth in Transition Economies," Journal of Money, Credit, and Banking, Vol. 29, No. 3, (August), pp. 381-99.

Lybek, T., 1998, "Elements of Central Bank: Autonomy and Accountability," Monetary and Exchange Affairs Department OP/98/1 (Washington: International Monetary Fund).

1999, "Central Bank Autonomy, and Inflation and Output Performance in the Baltic States, Russia, and other Countries of the Former Soviet Union, 1995-97," IMF Working Paper 99/4 (Washington: International Monetary Fund).

Mehran, H., P. Ugolini, J.P. Briffaux, G. Iden, T. Lybek, S. Swaray, and P. Hayward, 1998, Financial Sector Development in Sub-Saharan African 
Countries, Occasional Paper No. 169 (Washington: International Monetary Fund).

Persson, T. and G. Tabellini, 1993, "Designing Institutions for Monetary Stability," Carnegie-Rochester Series on Public Policy, Vol. 39, pp. 53-84.

Posen A., 1993, "Why Central Bank Independence Does Not Cause Low Inflation," Finance and the International Economy, Vol. 7, pp. 4065.

1995, "Central Bank Independence and Disinflationary Credibility: A Missing Link?," Federal Reserve Bank of New York Staff Reports, (May), New York.

Rogoff, K., 1985, "The Optimal Degree of Commitment to an Intermediate Monetary Target," Quarterly Journal of Economics (November), pp. $1169-90$.

Sarel, M., 1996, "Nonlinear Effects of Inflation on Economic Growth," Staff Papers, International Monetary Fund, Vol. 43 (March), pp. 199215.

Sinclair, P., 2000, "Central Banks and Financial Stability," Bank of England Quarterly Bulletin (November), pp. 377-91.

Stella, P., 1997, "Do Central Banks Need Capital?," IMF Working Paper 97/83 (Washington: International Monetary Fund).

Stiglitz, J., 1998, "Central Banking in a Democratic Society," The Economist 146, No. 2, pp. 199-226.

Walsh, C., 1995, "Is New Zealand's Reserve Bank Act of 1989 an Optimal Central Bank Contract?," Journal of Money Credit and Banking, Vol. 27, No. 24 (November), pp. 1179-91. 



\section{Turnover of Central Bank Governors}

IN LATIN AMERICA

(Since the approval of the legal reform up to end-2000. Selected countries)

\begin{tabular}{|c|c|c|c|c|}
\hline Country & $\begin{array}{c}\text { Date of } \\
\text { approval of } \\
\text { legal reform }\end{array}$ & $\begin{array}{c}\text { No. of Central } \\
\text { Bank } \\
\text { Governors 1/ }\end{array}$ & $\begin{array}{c}\text { No. of } \\
\text { years 1/ }\end{array}$ & $\begin{array}{c}\text { Governors } \\
\text { per year }\end{array}$ \\
\hline Argentina & $\begin{array}{l}\text { September } \\
1992\end{array}$ & 3 & 9 & 0.33 \\
\hline Bolivia & October 1995 & 1 & 6 & 0.17 \\
\hline Brazil 2/ & $\begin{array}{l}\text { Law 64; Const. } \\
1988\end{array}$ & 4 & 7 & 0.57 \\
\hline Chile & October 1989 & 3 & 12 & 0.25 \\
\hline Colombia 3/ & August 1991 & 2 & 10 & 0.20 \\
\hline Costa Rica & November 1995 & 2 & 6 & 0.33 \\
\hline $\begin{array}{l}\text { Dominican } \\
\text { Republic 2/ }\end{array}$ & $\begin{array}{l}\text { Law 1940; } \\
\text { Const. } 1962\end{array}$ & 3 & 7 & 0.43 \\
\hline Guatemala 2/ & $\begin{array}{l}\text { Law 1945; } \\
\text { Const. } 1985\end{array}$ & 3 & 7 & 0.43 \\
\hline Honduras & December 1996 & 3 & 5 & 0.60 \\
\hline Mexico & December 1993 & 2 & 8 & 0.25 \\
\hline Paraguay & June 1995 & 2 & 7 & 0.29 \\
\hline Peru & January 1993 & 2 & 9 & 0.22 \\
\hline Uruguay & March 1995 & 3 & 7 & 0.43 \\
\hline Venezuela & December 1992 & 3 & 9 & 0.33 \\
\hline
\end{tabular}

1/ From the following year after the approval of the law. If approved during the first quarter of the year, that year is considered the initial one.

2 / Since the legal reform took place well before the period considered, governors' turnover is accounted only for the period 1995 onwards.

3 / Corresponds to the date when the new independent central bank board was appointed. 